\title{
Effect of temperature on defense parameters in Manila clam Ruditapes philippinarum challenged with Vibrio tapetis
}

\author{
Christine Paillard*, Bassem Allam, Radouane Oubella \\ Laboratoire des Sciences de l'Environnement Marin, Institut Universitaire Européen de la Mer, \\ Université de Bretagne Occidentale, Place Copernic, Technopole Brest-Iroise, 29280 Plouzané, France
}

\begin{abstract}
Brown Ring Disease (BRD), a vibriosis affecting the clam Ruditapes philippinarum, is present on the Atlantic coasts of Western Europe and is considered to be a cold water disease. The present work investigated the effect of temperature on immune response and its relationships with BRD development. Clams maintained at different temperatures $\left(8,14\right.$ and $\left.21^{\circ} \mathrm{C}\right)$ were experimentally challenged with the pathogen Vibrio tapetis, the etiologic agent of BRD. Results demonstrated significant effects of temperature on disease development and on hemolymph immune parameters including total and viable hemocyte counts, lysozyme and leucine aminopeptidase activities. Thirty days after challenge, clams maintained at $21^{\circ} \mathrm{C}$ displayed significantly higher values for all the measured immune parameters in comparison to specimens incubated at $14^{\circ} \mathrm{C}$. Improved performance of the immune system was associated with a low BRD prevalence. The recovery process, which occured mainly at $21^{\circ} \mathrm{C}$, was associated with high percentages of viable hemocytes and high activities of leucine amino-peptidase and lysozyme. This laboratory study clearly demonstrates that temperature strongly affects BRD development and clam immune response during infection. Favourable immune status at higher temperature may confer upon the clam a better capacity to fight the disease agent, and therefore to recover more easily.
\end{abstract}

KEY WORDS: Immunomodulation $\cdot$ Temperature $\cdot$ Hemocyte $\cdot$ Leucine aminopeptidase $\cdot$ Lysozyme $\cdot$ Disease $\cdot$ Clam $\cdot$ Vibrio

Resale or republication not permitted without written consent of the publisher

\section{INTRODUCTION}

Bivalve molluscs possess an open circulatory system and as a result hemocytes are present in sinuses throughout all soft tissues and in extrapallial fluids located between the external epithelium of the mantle and the shell (Cheng 1981, Paillard et al. 1996, Allam \& Paillard 1998). In bivalves, immune defense is nonspecific, and based on cellular and humoral factors. Hemocytes constitute the main line of defense against materials recognized as non-self; however, humoral factors, especially circulating enzymes and anti-microbial peptides, also play an important role because they possess various anti-microbial properties (Chu 1988, Cheng 1992, Roch 1999). Lysosomal enzymes such as leucine amino-peptidase (LAP) and lysozyme are particularly crucial because of their ability to hydrolyse protein components of foreign bacterial membranes (Hiroi et al. 1992, Lopez et al. 1997).
Vibrio tapetis is the bacterial agent responsible for Brown Ring Disease (BRD) in the clams Ruditapes philippinarum and Ruditapes decussatus (Paillard et al. 1989, 1994, Paillard \& Maes 1990, Borrego et al. 1996). This disease occurs in wild and reared clam populations of France, England, Ireland, Spain and occasionally Italy, but has never been reported in Japan where $R$. philippinarum originates (Paillard et al. 1994, Allam et al. 2000b). V. tapetis colonizes the periostracal lamina, inhibits the normal process of shell biomineralization and thereby provokes an accumulation of melanized organic shell matrix on the inner face of the shell (Paillard \& Maes 1995a,b). The pathogen is mainly detected in the extrapallial fluids, on the mantle edge epithelium, and on the periostracal lamina (Paillard 1992, Allam et al. 1996). In severely infected clams, V. tapetis can be found within cells on the digestive gland (Plana 1995, Plana et al. 1996). Experimen- 
tal induction of the disease after $V$. tapetis challenge performed under standard conditions $\left(14^{\circ} \mathrm{C}, 33 \%\right)$ has shown that physiological functions such as nutrition and the immune defense system are severely affected in diseased clams (Oubella et al. 1994, 1996, Paillard et al. 1994, Plana 1995, Plana et al. 1996). Generally, at $14^{\circ} \mathrm{C}$, the immune response in hemolymph, during the development of $\mathrm{BRD}$, displays a 2-phase pattern: an early induction of cellular and humoral response in hemolymph (total hemocyte counts [THC] and enzymatic activities such as leucine aminopeptidase and lysozyme), followed by an inhibition of these defense parameters (Oubella et al. 1993, 1994, Paillard et al. 1994, Allam et al. 2000b). In severely infected clams, a concomitant increase in THC in the extrapallial fluids is measured suggesting their mobilisation to the site of infection (Oubella et al. 1993, 1994, Allam et al. 2000a). Mass mortalities of BRD-infected clams can result from the decline of metabolic activity, sometimes associated with a septicemic invasion of $V$. tapetis in hemolymph and tissues (Plana et al. 1996, Allam et al. 2002).

In marine invertebrates, disease prevalence is controlled by environmental factors (Harvell et al. 1999). In the case of BRD, field studies have suggested the influence of temperature on disease prevalence (Paillard et al. 1997). Along the French Atlantic coast, there is a clear boundary at the Loire river; the observed BRD prevalences ranged between 0 and $3 \%$ for the sites located south of the Loire, but ranged between 20 and $45 \%$ in sites north of Loire (Paillard et al. 1997). These inter-site prevalence variations could be explained by the pattern of extreme temperatures existing in the south (Paillard et al. 1997). Moreover, Vibrio tapetis is very sensitive to extreme temperatures; its in vitro growth is inhibited under $4^{\circ} \mathrm{C}$ and above $25^{\circ} \mathrm{C}$ (Paillard et al. 1997). Laboratory experiments have also demonstrated the effect of temperature on BRD prevalence, i.e. elevated temperature inhibits the development of BRD and enhances shell repair process (Paillard et al. 1997).

Variations of environmental parameters can also influence defense capacities in invertebrates and vertebrates. Studies have provided evidence for reduced immune function and increased infectious diseases and death rates during the winter for many vertebrates species (Afoke et al. 1993, Lochmiller et al. 1994). During the winter, immune factors may be low in these animals and opportunistic disease agents appear to overwhelm host defenses (Demas \& Neslon 1996, 1998, Nelson \& Demas 1996). In marine bivalves, environmental temperatures significantly modulate cellular and humoral activities (Feng \& Feng 1974, Fisher 1988). Seasonal, extreme and short-term temperature variations affect many parameters related to the immune functions (hemocyte counts and functions such as spreading, locomotion, and phagocytosis) (Fisher et al. 1987, 1989, Auffret \& Oubella 1994, Oubella 1996). In the eastern oyster Crassostrea virginica hemocyte counts and phagocytosis are generally less in winter compared to summer (Feng \& Canzonier 1970, Fisher et al. 1989). However, other activities, such as locomotion, spreading of hemocytes, and lysozyme levels in the serum display a different pattern with a significant decrease in summer (Feng \& Canzonier 1970, Fisher et al. 1989). In the hostpathogen interaction Crassostrea virginica-Perkinsus marinus, oysters exhibit greater THC and phagocytic activity at high temperatures when the prevalence and susceptibility to Perkinsus marinus are also high (Chu \& La Peyre 1993). The relationships between defense parameters modulated by temperature and disease susceptibilty to pathogens remain unclear and may vary depending on each host-pathogen model.

Although there is evidence regarding the impact of temperature on BRD prevalence in the field, nothing is known about the relationship between defenserelated parameters and BRD susceptibility and recovery at different temperatures. The purpose of this study is to evaluate the effect of temperature on immune response and its relationship to BRD syndrome.

\section{MATERIALS AND METHODS}

Specimens. Adult clams Ruditapes philippinarum ( 30 to $40 \mathrm{~mm}$ ) with no clinical signs of BRD were collected from natural stocks in the Bay of Brest (Lanveur, Finistere, France). Two different experiments (Expts 1 and 2) were performed at the same time of year (autumn). Each experiment used 600 clams.

Bacterial strain. For the challenge experiments, the virulent Vibrio tapetis strain (P16), previously isolated from diseased Ruditapes philipinarum in the Gulf of Morbihan (Tascon, Morbihan, France), was used. Bacteria were grown in marine agar (Difco 2216) at $18^{\circ} \mathrm{C}$ for $72 \mathrm{~h}$ before inoculation experiments.

Animal handling and sampling. After collection, clams were maintained for $3 \mathrm{~d}$ in marine aquaria (temperature: $14^{\circ} \mathrm{C} \pm 0.1^{\circ} \mathrm{C}$; salinity: $34 \pm 1 \%$ ). The clams were subdivided into 3 batches of 200 individuals. The first batch was maintained at $14^{\circ} \mathrm{C}$. For the other 2 batches, the temperature was progressively increased or decreased $\left(1^{\circ} \mathrm{C} \mathrm{d}^{-1}\right)$ to $21^{\circ} \mathrm{C}$ or $8^{\circ} \mathrm{C}$. Water temperature in the aquaria was controlled by an electronic thermostat system. After being maintained for $2 \mathrm{wk}$ at these 3 different temperatures $\left(8,14\right.$, or $\left.21^{\circ} \mathrm{C}\right)$, each batch was divided into 2 subgroups (100 clams each): the first subgroup was challenged with Vibrio tapetis as previously described (Paillard \& Maes 1990) while 
the second one was injected with sterile seawater (SSW). All procedures (emersion, inoculation) were performed in rooms maintained at 8,14 or $21^{\circ} \mathrm{C}$, depending on clam batches, to avoid any change in temperature. Challenged and control clams were incubated in aerated marine aquaria at the above conditions for $4 \mathrm{wk}$. They were fed daily with cultured algae (Isochrysis galbana and Dunaliella euchlora). Dead clams were collected daily and counted.

Hemolymph was collected from control and challenged clams as described by Auffret \& Oubella (1995) at different time intervals: $3,14,24,30 \mathrm{~d}$ for the first experiment (10 clams sample ${ }^{-1}$ ), and $0,14,30 \mathrm{~d}$ for the second one ( 20 clams sample ${ }^{-1}$ ). Time zero clams were sampled before the challenge and corresponded to acclimated clams not submitted to the overnight emersion before the inoculation procedure already described by Paillard \& Maes (1990).

Hemolymph immune parameters. Total and dead hemocyte counts: A filtered solution of $0.2 \%$ ice-cold SSW-trypan blue was added (v/v) to hemolymph samples to stain dead and damaged cells. Total hemocytes and dead cells were simultaneously counted with a hemacytometer. Results are presented as millions of cells $\mathrm{ml}^{-1}$ for THC and as percentages for dead cells (PDC).

Protein measurement: Hemolymph subsamples were kept in ice cooled vials. Protein determination was made on the hemolymph samples by the method of Bradford (1976) using bovine serum albumin as a standard measured at $595 \mathrm{~nm}$ on a spectrophotometer. The values were expressed as $\mathrm{mg}$ protein $\mathrm{ml}^{-1}$ of hemolymph.

LAP activity: The LAP activity was determined in hemolymph diluted with deionized water (1:9) by using the method of Oubella et al. (1994). Briefly, after hydrolysis at neutral $\mathrm{pH}$, the substrate (L-leucylnaphtylamide) (Sigma reagents, ref. 61538) produces L-leucyl-naphtylamine. The absorbance of the dye product is measured by spectrophotometer at $580 \mathrm{~nm}$. The LAP activity was expressed as specific activity (Sigma units $\mathrm{ml}^{-1} \mathrm{mg}$ of proteins).

Lysozyme activity measurement: Lysozyme concentration was determined spectrophotometrically according to the method of Shugar (1952) with modifications as previously described by Allam \& Paillard (1998). Chicken egg white lysozyme (CEW, Sigma) served as the standard. Lysozyme activity is given as concentration of CEW lysozyme equivalent expressed in $\mathrm{gg} \mathrm{mg}^{-1}$ protein.

Characterisation and classification of BRD syndrome. Disease progression was monitored according to the description of Paillard \& Maes (1994). According to these authors, conchiolin deposit stages (CDS) range from microscopic brown spots on the inner face of the shell in the earliest stage (CDS 1) to a complete thick brown ring in the most advanced stage (CDS 7). Three main conchiolin deposit groups (CDG) were considered: CDG I (beginning of infection): CDS 1 and 2 ; CDG II (intermediate infection): CDS 3; and CDG III (well-developed infection): CDS 4 to 7 .

Three stages of shell repair or recovery (SRS) were also described by Paillard \& Maes in 1994. Stage 1 corresponds to the apposition of calcified concretions. The partial covering of the deposit by wide calcified plates corresponds to Stage 2. In Stage 3, the brown deposit is completely covered by shell layers. By considering the process of conchiolin deposit formation and the process of shell repair together, 3 phases of the disease are defined. The first phase corresponds to the development of the disease and is characterized only by accumulation of a conchiolin deposit. The second phase is characterized by the 2 processes, conchiolin deposit and shell repair, occurring simultaneously. The third phase corresponds to the end of the recovery process, when the clams have totally covered the conchiolin deposit.

Statistical analysis. Normality fitting was performed using a Kolgmorgorov-Smirnov test. Where necessary, parameters were expressed as $\log _{10}$ or arc sines. In the tables and figures, data represent non-transformed values.

For both experiments and for each hemolymph parameter, differences between inoculated and control clams and between temperatures were assessed using Student's $t$-test. Significance level was defined at $\alpha=$ 0.05 .

For the comparison of multiple factors and their interactions (experiment, temperature, date, test), the non-parametric test, the Multiple Range Test (MRT) (confidence level at 95\%) and also ANOVA tests (1-way or 4 -way interactions at the $95 \%$ confidence level, if normality and variance tests allowed parametric tests) were used.

For testing the difference between both experiments, we used only values obtained from the same period of sampling (Day 14 and Day 30 after challenge). Mean deviations were calculated for both experiments to harmonize the data for statistical tests (regression analysis, linear model, confidence level, at 90 or $99 \%$, ANOVA tests at $95 \%$ and MRT at the $95 \%$ confidence level).

To compare the effect of temperature on each hemolymph parameter of challenged clams a bacterial challenge indicator (BCI) was created. For each immune parameter, this indicator was calculated as

$$
\mathrm{BCI}=\left[\left(I_{1 \ldots \mathrm{n}}\right)-C_{\mathrm{m}}\right]
$$

where $I_{1 \ldots \mathrm{n}}$ corresponds to values from 1 to $\mathrm{n}$ individuals of Vibrio tapetis-inoculated clams $(10<\mathrm{n}<21)$ and 

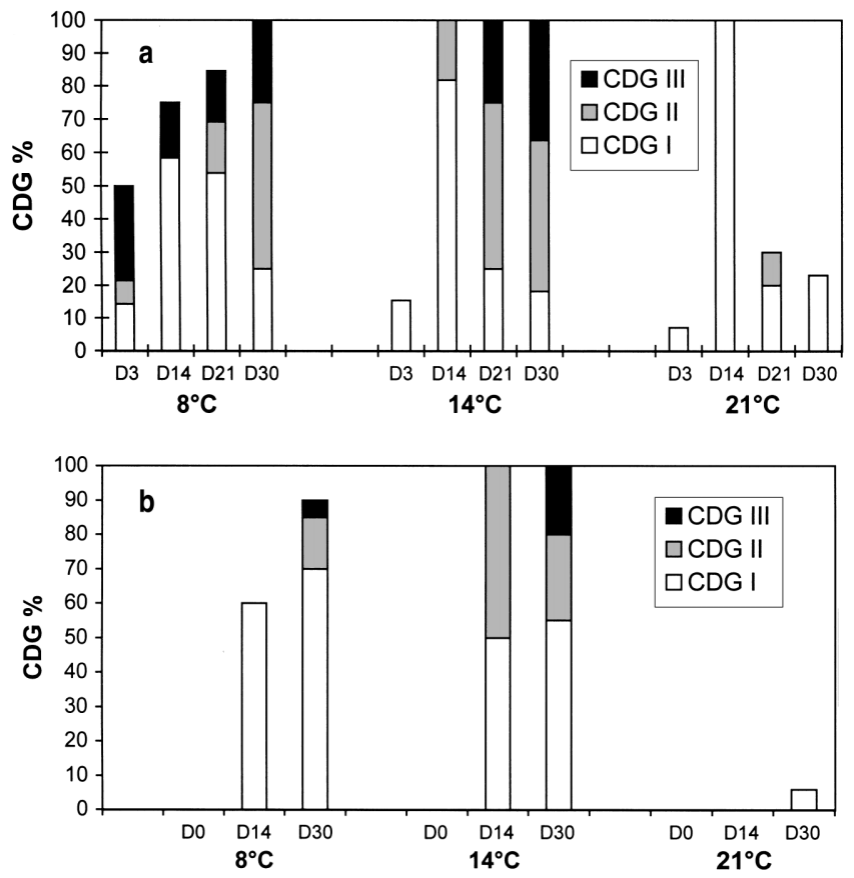

Fig. 1. Vibrio tapetis infecting Ruditapes philippinarum. Conchiolin deposit group (CDG) prevalence in (a) Expt 1 and (b) Expt 2. At each sampling, $\mathrm{n}=10$ and $\mathrm{n}=20$ for Expts 1 and 2 , respectively. D: day

$C_{\mathrm{m}}$ corresponds to the mean of all the data obtained from control individual clams.

For testing relationships between BRD development (CDS and CDG, SRS and phases of the disease) and hemolymph parameters, the linear regression test was used. All the data from Expts 1 and 2 were used together for these tests. This was performed on diseased and healthy clams together ( $\mathrm{n}=496$ to 502), or only on clams exhibiting shell repair $(n=88)$.

For the factorial correspondence analysis, the calculations were carried out on mean data of squared racine transformed values (Uniwin program).

\section{RESULTS}

\section{BRD diagnosis}

\section{BRD prevalence, Conchiolin Deposit Groups}

At $14^{\circ} \mathrm{C}$, all challenged clams collected on Day 14 and Day 30 displayed BRD signs in both experiments. In those incubated at $8^{\circ} \mathrm{C}, \mathrm{BRD}$ prevalence in challenged clams from Day 14 reached 75 and $60 \%$, in Expts 1 and 2, respectively. These percentages increased to 90 and $100 \%$ by Day 30 (Fig. 1). Although prevalence was similar on Day 30 in clams incubated at 14 and $8^{\circ} \mathrm{C}, \mathrm{BRD}$ development was significantly different between these batches. The CDG was lower at $8^{\circ} \mathrm{C}$ than at $14^{\circ} \mathrm{C}\left(\mathrm{CDG}\right.$ III $=25 \%$ at $8^{\circ} \mathrm{C}$ and $40 \%$ at $14^{\circ} \mathrm{C}$ in Expt $1 ; \mathrm{CDG}$ III $=5 \%$ at $8^{\circ} \mathrm{C}$ and $20 \%$ at $14^{\circ} \mathrm{C}$ in Expt 2). The conchiolin deposits were less developed in the second experiment than in the first one (18\% and $55 \%$ at CDG I, in Expt 1 and 2, respectively).

The development of BRD was relatively low in challenged clams incubated at $21^{\circ} \mathrm{C}$. During the first experiment, all clams exhibited BRD signs $15 \mathrm{~d}$ following challenge, but at very low CDG (100\% at CDG I). One month after challenge, $40 \%$ of these diseased clams had recovered, and BRD prevalence decreased to $23 \%$. During the second experiment, only $6 \%$ of the challenged clams collected on Day 30 displayed early signs of BRD (CDG I). At $21^{\circ} \mathrm{C}$, the clams exhibited significantly lower values of CDG than those incubated at 8 and $14^{\circ} \mathrm{C}$ (MRT tests).

BRD signs were not detected in control clams (injected with SSW) maintained at 14 and $21^{\circ} \mathrm{C}$, for both experiments. However, the control clams collected on Day 30 exhibited $20 \%$ BRD prevalence in batches incubated at $8^{\circ} \mathrm{C}$, for both experiments.

\section{Shell repair stages and disease phases}

At Day 30, the percentage of challenged clams displaying shell repair processes was higher at 21 and $14^{\circ} \mathrm{C}$ than at $8^{\circ} \mathrm{C}$. At $21^{\circ} \mathrm{C}$, the SRS reached $65 \%$, for both experiments (Fig. 2). One month following chal-
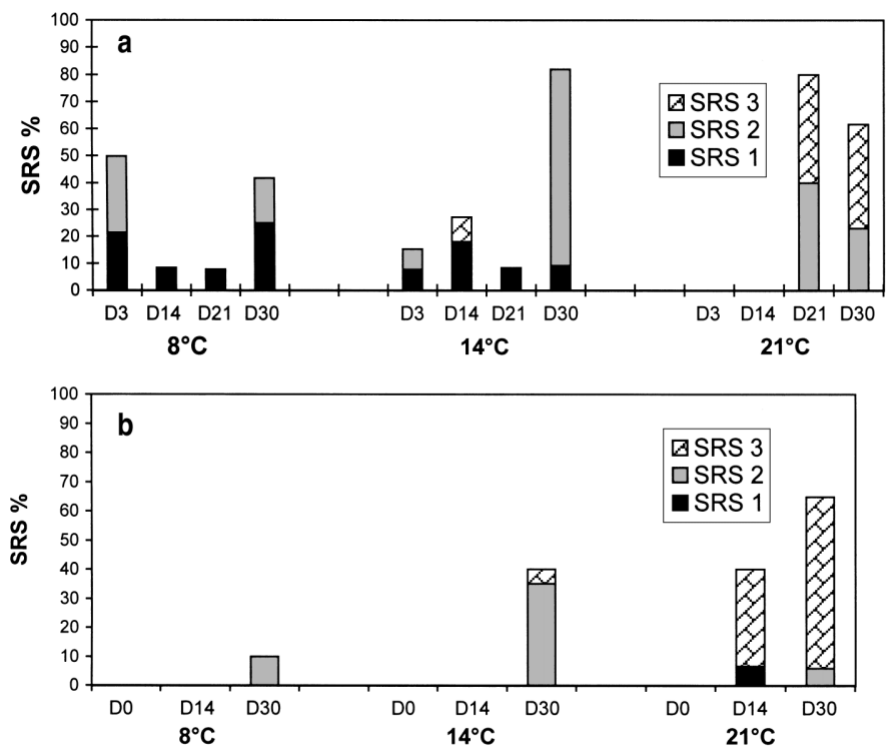

Fig. 2. Vibrio tapetis infecting Ruditapes philippinarum. Shell repair stage (SRS) prevalence in (a) Expt 1 and (b) Expt 2. At each sampling, $\mathrm{n}=10$ and $\mathrm{n}=20$ for Expts 1 and 2, respectively. D: day 
lenge, the percentage of total recovery (SRS 3) was high only in clams incubated at $21^{\circ} \mathrm{C}$, reaching 40 and $55 \%$ in Expts 1 and 2, respectively. Complete recovery was observed in only 5 to $10 \%$ of clams maintained at $14^{\circ} \mathrm{C}$, and never in those held at $8^{\circ} \mathrm{C}$, for both experiments. In Expt 1, the decrease in BRD prevalence between Day 14 (100\%, Fig. 1) and Day 21 (30\%) was associated with the process of complete recovery (SRS 3) which reached $40 \%$ on Day 21 .

The clams conditioned at $21^{\circ} \mathrm{C}$ showed significantly higher values of SRS and disease phases than those incubated at 8 and $14^{\circ} \mathrm{C}$ (MRT tests).

\section{Clam mortality}

In Expt 1, clam mortality was low in all batches and remained below $10 \%$ at the end of the experiment. Similarly, a very low mortality ( 2 to $5 \%$ ) occurred during the Expt 2 in control and experimental clams maintained at 8 and $14^{\circ} \mathrm{C}$. At $21^{\circ} \mathrm{C}$, mortality at Day 30 was low $(5 \%)$ in challenged clams, but reached $30 \%$ in controls.

\section{Temperature effects on hemolymph parameters}

Using pooled data from both experiments, temperature significantly modulated all the immune parameters, except protein (ANOVA tests, $\mathrm{p}<0.002$ ) (Table 1).

\section{Total hemocyte counts}

THC level. In control clams, for all samples in both experiments, significantly higher THC were observed in clams incubated at $21^{\circ} \mathrm{C}$ in comparison with specimens

Table 1. Analysis of variance for the mean deviation of 5 defense parameters (total hemocyte count, $\mathrm{THC}_{\text {; }}$ percentage of dead cells, PDC; leucine amino-peptidase, LAP; lysosyme, LYSO; protein) with 4 factors without interactions (temperature, test, experiment and date) considering data for both experiments $(n=180)$. Significant $p$-values are given in bold

\begin{tabular}{|lccccc|}
\hline Factors & THC & PDC & LAP & LYSO & Protein \\
\hline Temp. & $<\mathbf{0 . 0 0 0 0 1}$ & $<\mathbf{0 . 0 0 0 0 1}$ & $<\mathbf{0 . 0 0 0 0 1}$ & $\mathbf{0 . 0 0 2 1 1}$ & 0.1952 \\
Test & $<\mathbf{0 . 0 0 0 0 1}$ & $\mathbf{0 . 0 0 0 2}$ & $\mathbf{0 . 0 0 1 1}$ & $\mathbf{0 . 0 0 3 9}$ & 0.7672 \\
Expt & 0.6689 & $\mathbf{0 . 0 4 2 4}$ & 0.2654 & 0.2299 & 0.7963 \\
Date & 0.4998 & $\mathbf{0 . 0 0 2 2}$ & 0.5536 & $\mathbf{0 . 0 4 5 6}$ & 0.192 \\
\hline
\end{tabular}

held at $8^{\circ} \mathrm{C}(\mathrm{MRT}$, Student's $t$-test, $\mathrm{p}<0.05$, ANOVA tests) (Fig. 3). Differences between clams incubated at $21^{\circ} \mathrm{C}$ and those held at $14^{\circ} \mathrm{C}$ were significant only in clams from Expt 2 collected on Day 14 and Day 30.

Similar results were observed in Vibrio tapetis inoculated clams from Expt 1 with high THC values at higher temperatures (Fig. 3). In contrast, inoculated clams from Expt 2 showed higher THC at 14 than at 8 and $21^{\circ} \mathrm{C}$. These differences were significant only on Day 14 (Student's $t$-test, $\mathrm{p}<0.05$ ).

THC pattern. On Day 14, using pooled data from clams incubated at all temperatures and both experiments, the mean deviation of THC was significantly higher in inoculated clams than in controls (ANOVA tests, $\mathrm{p}<0.00001)$. At $14 \mathrm{~d}$, the THC pattern in challenged clams was different between the first and the second experiments. In Expt 1, for all temperatures, THC on Day 24 were significantly lower than on Day 14 (Student's $t$-test, $\mathrm{p}<0.05)$. This difference was greater at 14 than at 21 and $8^{\circ} \mathrm{C}$ (on Day 30, the bacterial challenge indicator total hemocyte count $\left[\mathrm{BCI}_{\mathrm{THC}}\right]$ values are all negative and $\mathrm{BCI}_{\mathrm{THC}}$ is significantly higher at $14^{\circ} \mathrm{C}$ than at 21 and $8^{\circ} \mathrm{C}$, MRT tests) (Table 2). But in Expt 2, for all temperatures, no significant THC decrease in challenged clams between Day 14 and Day 30 was noticed (Student's $t$-test, $\mathrm{p}>0.05$ ).

THC and BRD relationship. No significant relationships between hemocyte concentrations and BRD 
Table 2. Bacterial challenge indicator $\left(\mathrm{BCI}_{i}\right.$ mean $\left.\pm \mathrm{SE}\right)$ in Expt 1 and Expt 2 performed at 3 temperatures: 8, 14 and $21^{\circ} \mathrm{C}$. Total hemocyte count, THC; percentage of dead cells, PDC; leucine amino-peptidase, LAP; lysosyme, LYSO; protein. Significant values are given in bold. Lettering indicates significant differences between temperature for each parameter and date (using MRT tests)

\begin{tabular}{|c|c|c|c|c|c|c|c|c|}
\hline & \multicolumn{2}{|c|}{ THC } & \multicolumn{2}{|c|}{ PDC } & \multicolumn{2}{|c|}{ LAP } & \multicolumn{2}{|c|}{ LYSO } \\
\hline & Day 14 & Day 30 & Day 14 & Day 30 & Day 14 & Day 30 & Day 14 & Day 30 \\
\hline $\begin{array}{l}\text { Expt } 1 \\
8^{\circ} \mathrm{C}\end{array}$ & $\begin{array}{r}401.3 \\
+157.91\end{array}$ & $\begin{array}{r}-636 \\
\pm 80.37\end{array}$ & $\begin{array}{r}\mathbf{0 . 9 2}^{\mathbf{a}} \\
\pm 0.71\end{array}$ & $\begin{array}{r}\mathbf{2 . 6 9}^{\mathbf{a}} \\
\pm 0.83\end{array}$ & $\begin{array}{r}\mathbf{1 . 6 7}^{\mathbf{a}} \\
\pm 1.35\end{array}$ & $\begin{array}{l}-3.15 \\
\pm 0.87\end{array}$ & $\begin{array}{r}7.36 \\
\pm 2.1\end{array}$ & $\begin{array}{l}-\mathbf{7 . 1 6} \mathbf{a}^{\mathrm{a}} \\
\pm 0.94\end{array}$ \\
\hline $14^{\circ} \mathrm{C}$ & $\begin{array}{r}666.72 \\
\pm 159.49\end{array}$ & $\begin{array}{r}-1217.94^{\mathbf{a}} \\
\pm 230.34\end{array}$ & $\begin{array}{l}-\mathbf{- 0 . 0 3}^{\mathbf{a}} \\
\pm 0.28\end{array}$ & $\begin{array}{l}1.57^{\mathrm{a}} \\
\pm 0.5\end{array}$ & $\begin{array}{r}\mathbf{2 . 0 6} \mathbf{6}^{\mathbf{a}} \\
\pm 3.59\end{array}$ & $\begin{array}{r}-3.94 \\
\pm 4.31\end{array}$ & $\begin{array}{r}\mathbf{9 . 7 5}^{\mathbf{a}} \\
\pm 2.35\end{array}$ & $\begin{array}{r}-6.39^{\mathbf{a}} \\
\pm 1\end{array}$ \\
\hline $21^{\circ} \mathrm{C}$ & $\begin{array}{r}768.2 \\
\pm 280.84\end{array}$ & 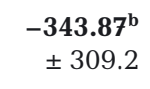 & $\begin{array}{r}\mathbf{2 . 3 3}^{\mathbf{b}} \\
\pm 0.31\end{array}$ & $\begin{array}{r}1.37^{\mathbf{b}} \\
\pm 0.43\end{array}$ & $\begin{array}{l}17.36^{\mathbf{b}} \\
\pm 5.46\end{array}$ & $\begin{array}{r}1.77 \\
\pm 4.63\end{array}$ & $\begin{array}{r}\mathbf{2 . 1 3}^{\mathbf{b}} \\
\pm 2.24\end{array}$ & $\begin{array}{r}\mathbf{8 . 3 1}^{\mathrm{b}} \\
\pm 1.82\end{array}$ \\
\hline $\begin{array}{l}\text { Expt } 2 \\
8^{\circ} \mathrm{C}\end{array}$ & $\begin{array}{r}\mathbf{3 2 1}^{\mathbf{a}} \\
+95.91\end{array}$ & $\begin{array}{l}1197.62^{\mathrm{a}} \\
\pm 403.71\end{array}$ & $\begin{array}{r}\mathbf{1 . 0 8}^{\mathbf{a}} \\
\pm 0.55\end{array}$ & $\begin{array}{r}0.47 \\
\pm 1.09\end{array}$ & $\begin{array}{r}-\mathbf{0 . 9 3}^{\mathbf{a}} \\
\pm 0.61\end{array}$ & $\begin{array}{r}1.78 \\
\pm 1.27\end{array}$ & 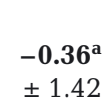 & $\begin{array}{l}\mathbf{5 . 4 3}^{\mathrm{a}} \\
\pm 2.7\end{array}$ \\
\hline $14^{\circ} \mathrm{C}$ & $\begin{array}{l}\mathbf{1 2 0 4 . 4 9}^{\mathbf{b}} \\
\pm 235.52\end{array}$ & 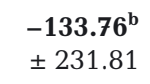 & $\begin{array}{r}\mathbf{4 . 2 6}^{\mathbf{b}} \\
\pm 1.33\end{array}$ & $\begin{array}{r}2.92 \\
\pm 1.01\end{array}$ & $\begin{array}{r}12.9^{\mathbf{b}} \\
\pm 3.95\end{array}$ & $\begin{array}{l}\mathbf{7 . 4 7} \mathbf{7}^{*} \\
\pm 1.3\end{array}$ & $\begin{array}{r}\mathbf{1 1 . 0 6}^{\mathbf{b}} \\
\pm 3.1\end{array}$ & $\begin{array}{c}-\mathbf{0 . 6 1} \\
\pm 3.64\end{array}$ \\
\hline $21^{\circ} \mathrm{C}$ & $\begin{array}{r}\mathbf{- 5 8 . 6}^{\mathbf{a}} \\
\pm 124.34\end{array}$ & $\begin{array}{r}-\mathbf{1 5 8 6 . 2 5}^{\mathrm{c}} \\
\pm 80.74\end{array}$ & $\begin{array}{r}2.61 \\
\pm 0.52\end{array}$ & $\begin{array}{r}0.7 \\
\pm 0.46\end{array}$ & $\begin{array}{r}\mathbf{1 . 9 2}^{\mathbf{a}} \\
\pm 2.61\end{array}$ & $\begin{array}{l}\mathbf{- 2 . 3 1 *} \\
\pm 4.91\end{array}$ & $\begin{array}{r}\mathbf{1 . 7 8}^{\mathbf{a}} \\
\pm 1.61\end{array}$ & $\begin{array}{r}\mathbf{5 . 6 6}^{\mathbf{a}} \\
\pm 2.47\end{array}$ \\
\hline
\end{tabular}

stages or SRS and disease phases were observed (linear regression tests, Table 3). An increasing tendency of THC with high CDG was noted (Kruskal-Wallis, $\mathrm{p}=$ 0.005; MRT tests, linear regression test, $\mathrm{p}=0.059$ ).

Percentage of dead cells

PDC level. The PDCs were significantly higher in clams incubated at $8^{\circ} \mathrm{C}$ than those held at 14 and $21^{\circ} \mathrm{C}$ for all clams (challenged and control), all samples and in both experiments (Student's $t$-test, $\mathrm{p}=0.05$, Fig. 4).

PDC pattern. There was no significant effect of temperature on the pattern of PDC (MRT tests and Student's $t$-test, $\mathrm{p}>0.05)$. On Day 30, in Expt 1, the bacterial challenge indicator percentage of dead cells $\left(\mathrm{BCI}_{\mathrm{PDC}}\right)$ was significantly higher at 8 and 14 than at $21^{\circ} \mathrm{C}$ (MRT tests). These latter results were not significant in Expt 2.

$P D C$ and $B R D$ relationship. When all clams were analysed together, the PDC showed a slight but significant increase with development of the disease (Table 3). (Linear regression tests, $\mathrm{p}=0.0002$, and $\mathrm{p}=$ 0.001, with CDS and CDG, respectively). Asymptomatic clams had a significantly lower percentage of dead cells than clams exhibiting CDG I, II and III of the syndrome (MRT tests, Kruskal-Wallis, p=0.00001).

For clams displaying SRP, the PDC decreased significantly with the process of recovery. There was a negative relationship between PDC and SRS and disease phases (regression linear tests, $p=0.0047$ and $p=0.0025$, respectively). With analysis of all clams, the healthy individuals (asymptomatic and recovered clams, SRS 3) exhibited a significantly lower percentage of dead cells than diseased clams with no shell repair (SRS 0) or weak shell repair (SRS 1) (MRT tests). Similarly, asymptomatic clams (phase 0) and recovered clams (phase 3) exhibited

Table 3. Linear regression tests between defense parameters (total hemocyte count, THC; percentage of dead cells, PDC; leucine amino-peptidase, LAP; lysosyme, LYSO; protein) and Brown Ring Disease (BRD) susceptibility (conchiolin deposit stages, CDS; conchiolin deposit groups, CDG; shell repair stages, SRS; disease phases)

\begin{tabular}{|c|c|c|c|c|}
\hline & CDS & CDG & SRS & $\begin{array}{c}\text { Disease } \\
\text { phases }\end{array}$ \\
\hline THC & No & $\begin{array}{c}+ \\
\mathrm{r}^{2}=0.71 \\
\mathrm{p}=0.059 \\
\mathrm{n}=499\end{array}$ & No & No \\
\hline PDC & $\begin{array}{c}+ \\
\mathrm{r}^{2}=2.81 \\
\mathrm{p}=0.0002 \\
\mathrm{n}=499\end{array}$ & $\begin{array}{c}+ \\
\mathrm{r}^{2}=3.1 \\
\mathrm{p}=0.001 \\
\mathrm{n}=499\end{array}$ & $\begin{array}{c}- \\
\mathrm{r}^{2}=8.9 \\
\mathrm{p}=0.0047 \\
\mathrm{n}=88\end{array}$ & No \\
\hline LAP & $\begin{array}{c}- \\
\mathrm{r}^{2}=1.5 \\
\mathrm{p}=0.006 \\
\mathrm{n}=499\end{array}$ & $\begin{array}{c}- \\
\mathrm{r}^{2}=1.18 \\
\mathrm{p}=0.0149 \\
\mathrm{n}=499\end{array}$ & $\begin{array}{c}+ \\
\mathrm{r}^{2}=10.04 \\
\mathrm{p}=0.0025 \\
\mathrm{n}=88\end{array}$ & No \\
\hline $\begin{array}{r}\text { Lysozyme } \\
\qquad p\end{array}$ & $\begin{array}{c}\mathrm{r}^{2}=1 \\
\mathrm{p}=0.0379 \\
\mathrm{n}=496\end{array}$ & $\begin{array}{c}+ \\
\mathrm{r}^{2}=1.09 \\
\mathrm{p}=0.02 \\
\mathrm{n}=496\end{array}$ & $\begin{array}{c}+ \\
\mathrm{r}^{2}=4.11 \\
\mathrm{p}=0.0629 \\
\mathrm{n}=88\end{array}$ & $\begin{array}{c}+ \\
\mathrm{r}^{2}=1.99 \\
\mathrm{p}=0.0016 \\
\mathrm{n}=499\end{array}$ \\
\hline Protein & No & No & No & $\begin{array}{c}- \\
\mathrm{r}^{2}=2.2 \\
\mathrm{p}=0.0008 \\
\mathrm{n}=502\end{array}$ \\
\hline
\end{tabular}


lower concentrations of dead cells than those in Phase 1 and 2 of the disease (MRT tests, Kruskal-Wallis, $\mathrm{p}<0.00001$ ).

\section{Leucine amino peptidase}

LAP level. In both experiments and all clams, the LAP activity was higher in clams incubated at $21^{\circ} \mathrm{C}$ than those held at $8^{\circ} \mathrm{C}$. Significant differences were noted for all sampling intervals in both control and challenged clams from the first experiment, and in both control and challenged clams collected on Day 30 during Expt 2 (Student's t-test, p < 0.05) (Fig. 5).

Data from both experiments show that the mean deviations for LAP were significantly higher at 21 and $14^{\circ} \mathrm{C}$ than at $8^{\circ} \mathrm{C}$ (on Day 30, they were also significantly higher at $21^{\circ} \mathrm{C}$ than at $14^{\circ} \mathrm{C}$ ) (Student's $t$-test, $\mathrm{p}<0.05$, MRT tests, ANOVA tests).

LAP pattern. A significant effect of temperature on the LAP pattern was measured in challenged clams in comparison to controls collected at the end of the experiments. On Day 30, for both experiments, the absolute value of $\mathrm{BCI}_{\mathrm{LAP}}$ was higher at $14^{\circ} \mathrm{C}$ than at $8^{\circ} \mathrm{C}$ and $21^{\circ} \mathrm{C}$ (significant only in Expt 2) (Table 2).

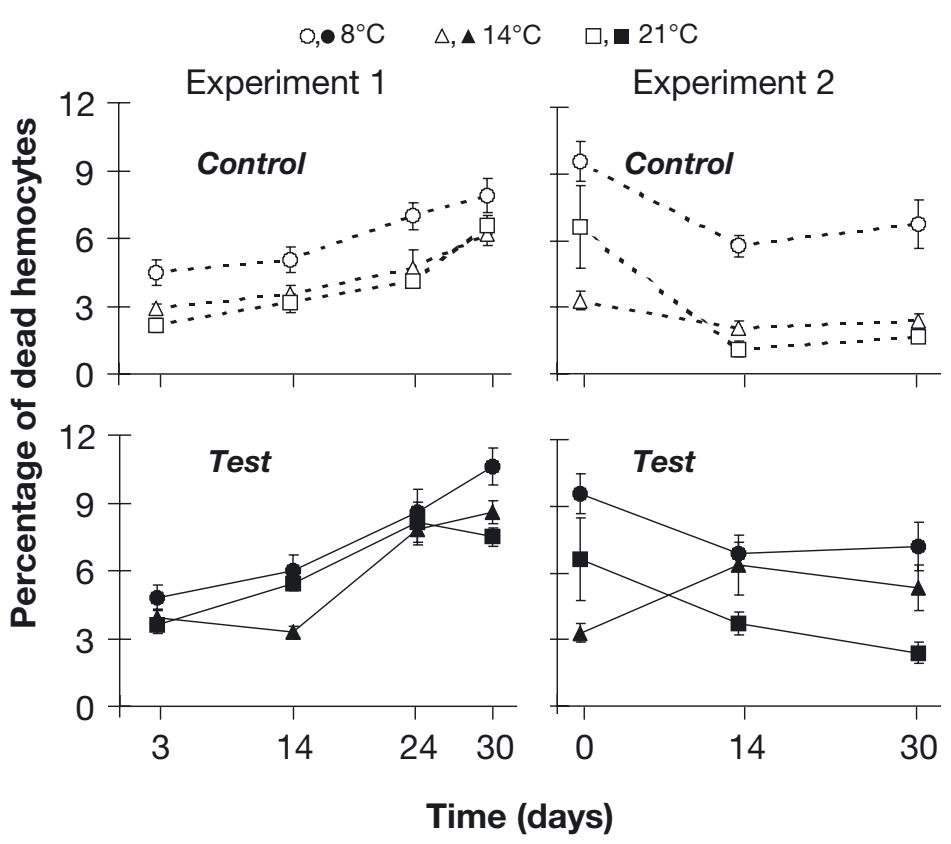

Fig. 4. Vibrio tapetis infecting Ruditapes philippinarum. Percentage of dead cells (PDC) in control and $V$. tapetis challenged (test) clams, maintained at 8,14 and $21^{\circ} \mathrm{C}$. Vertical bars are standard error of the mean ( $\mathrm{n}=10$ in Expt 1 and $\mathrm{n}=20$ in Expt 2)

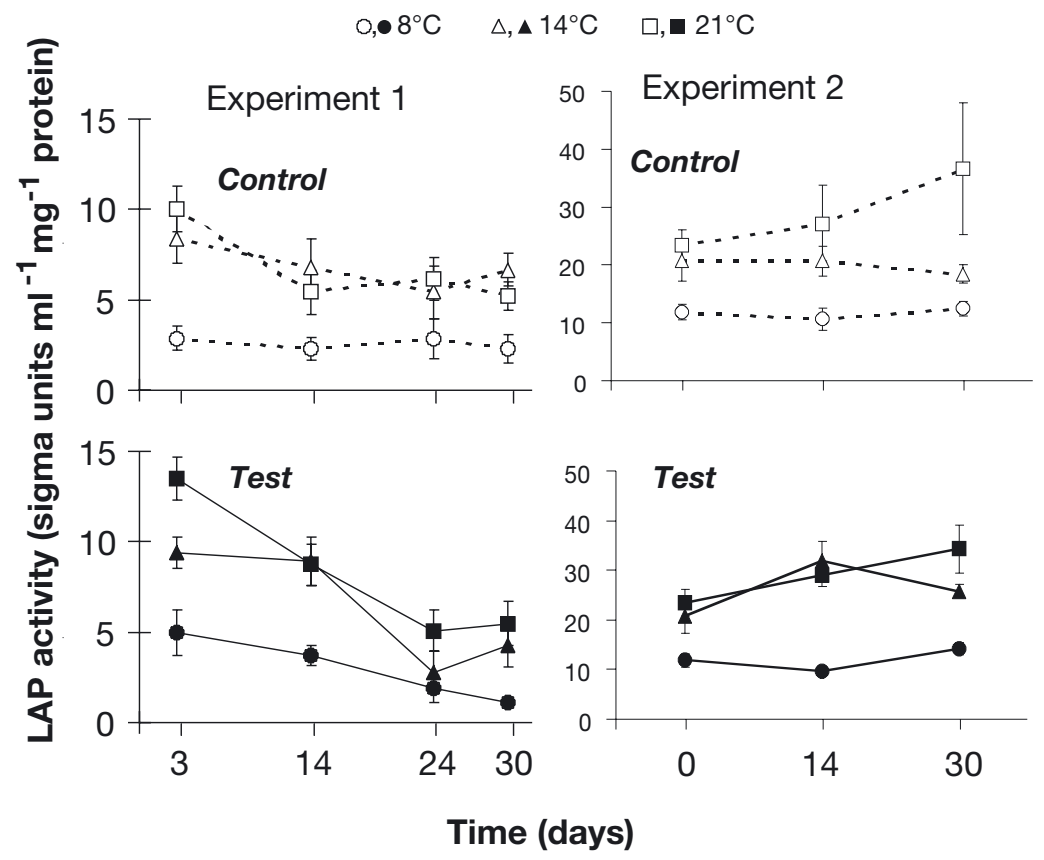

Fig. 5. Vibrio tapetis infecting Ruditapes philippinarum. Leucine aminopeptidase (LAP) activities in control and $V$. tapetis challenged (test) clams, maintained at 8,14 and $21^{\circ} \mathrm{C}$. Vertical bars are standard error of the mean $(n=10$ in Expt 1 and $n=20$ in Expt 2)

$L A P$ and BRD relationship. When diseased and healthy clams are analyzed together, regression tests show that the LAP activity was negatively correlated with CDS and CDG (linear regression tests, $\mathrm{p}=0.006$ and $\mathrm{p}=0.0149$, respectively) (Table 3).

Further analyses of clams displaying a shell repair process have shown that the LAP activity increased significantly with the process of recovery. There is a statistically positive relationship between LAP activity and SRS, and disease phases at the $99 \%$ confidence level (regression linear tests, $\mathrm{p}=0.0025$ and $\mathrm{p}=$ 0.0010 , respectively). Recovered clams (SRS 3, Phase 3) showed significantly higher LAP activity than clams in SRS and disease Phases 0, 1 and 2 (MRT tests, Kruskal-Wallis, p = 0.0013).

\section{Lysozyme}

LYSO level. In control clams from both experiments, the specific lysozyme activities were always higher in clams incubated at $8^{\circ} \mathrm{C}$ compared to clams held at $21^{\circ} \mathrm{C}$ (significant differences detected only in Expt 1, Student's $t$-test, $\mathrm{p}<0.05$ ) (Fig. 6). Similarly, the mean deviation for lysozyme activity was sig- 


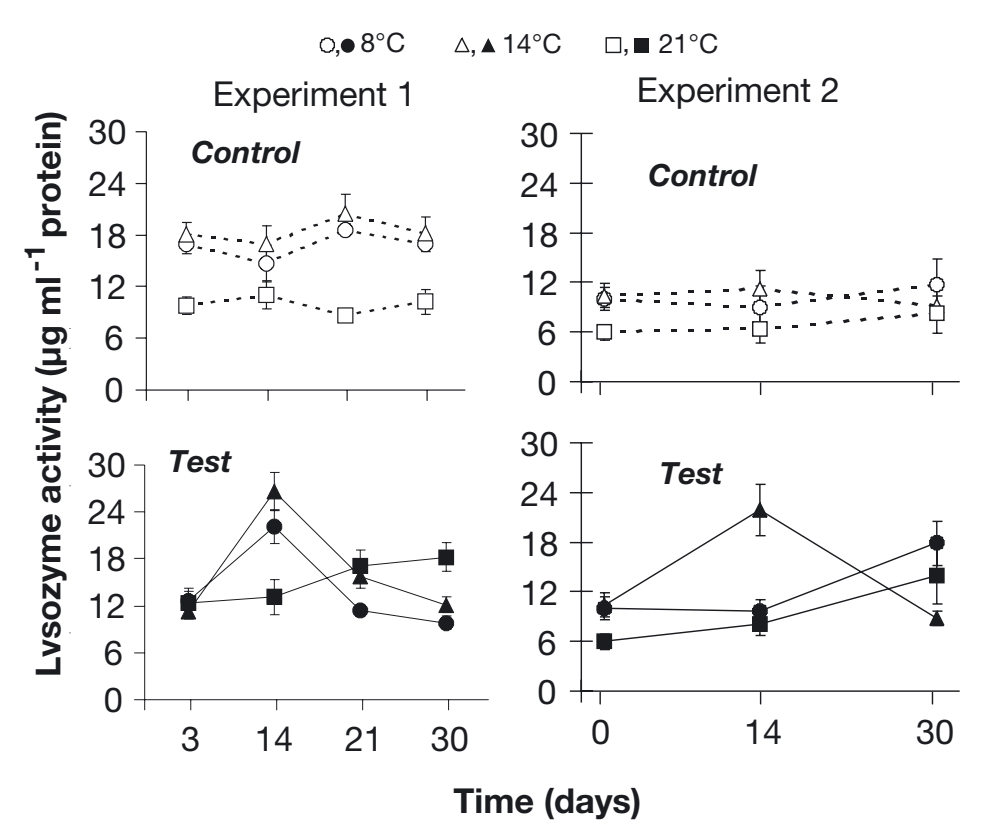

Fig. 6. Vibrio tapetis infecting Ruditapes philippinarum. Lysozyme activities in control and $V$. tapetis challenged (test) clams, maintained at 8, 14 and $21^{\circ} \mathrm{C}$. Vertical bars are standard error of the mean $(\mathrm{n}=10$ in Expt 1 and $n=20$ in Expt 2)

nificantly higher at 8 and $14^{\circ} \mathrm{C}$ than activity measured at $21^{\circ} \mathrm{C}$ (MRT and ANOVA tests). In contrast, challenged clams from both experiments collected on Day 30 displayed a higher lysozyme level at $21^{\circ} \mathrm{C}$ than at $14^{\circ} \mathrm{C}$. In Expt 1 , the specific lysozyme activity was also significantly higher at 21 than at $8^{\circ} \mathrm{C}$ (MRT tests).

LYSO pattern. For both experiments, the lysozyme pattern between Day 14 and Day 30 was dependent upon the incubation temperatures. At $14^{\circ} \mathrm{C}$, the lysozyme activity decreased in both experiments between Day 14 and Day 30 (Fig. 6). In contrast, at $21^{\circ} \mathrm{C}$, the lysozyme activity increased progressively between Day 14 and Day 30 and reached significantly higher values than controls incubated at the same temperature by the end of the experiment. The temperature effect on bacterial challenge indicator lysozyme (BCI $\mathrm{BYSO}_{\mathrm{LY}}$ ) confirms this tendency for both experiments (Table 2). At Day 30, BCI $\mathrm{L}_{\mathrm{LYso}}$ was significantly higher at $21^{\circ} \mathrm{C}$ than at $14^{\circ} \mathrm{C}$ (MRT tests).

LYSO and BRD relationship. Lysozyme activity increased with the development of the disease (Table 3). A statistically positive relationship between lysozyme activity and CDS and CDG was noted (regression linear tests, $\mathrm{p}=0.0379$ and $\mathrm{p}=0.02$, respectively).

For clams displaying a shell repair, lysozyme activity increased significantly with the process of recovery (SRS, $p=0.0629$ ). In fact, healthy clams exhibited a significantly lower lysozyme activity compared to BRD clams that had not begun the shell repair pro- cess (SRS 0) and those which completed the shell repair process (i.e. recovered clams, SRS 3) (MRT tests). Similarly, the lysozyme activity increased significantly with the disease phases (regression linear test, $\mathrm{p}=$ 0.0016).

\section{Protein}

Protein level. No significant effect of temperature was noted on protein concentrations in control or challenged clams in either experiment.

Protein pattern. No significant effect of temperature on the pattern of protein content was noticed (MRT tests).

Protein and BRD relationship. No relationships were found between protein activity and BRS (CDS and CDG). In fact, recovered clams exhibited significantly lower protein concentrations than healthy or CDG 1 and CDG 2 clams (MRT tests).

No relationship was found between protein concentration and SRS. Healthy clams and diseased clams with no shell repair showed significant higher protein concentrations in hemolymph compared to recovered clams (MRT tests).

Similarly, asymptomatic clams (Phase 0) had significantly higher protein concentrations than individuals in Phase 3 of the disease (MRT tests).

\section{Experiment effects on hemolymph parameters}

Significant differences were observed between the experiments for all measured parameters, except protein content, both in control and challenged clams. However, no differences were observed between experiments in mean deviation data for all studied hemolymph parameters, except the percentage of dead hemocytes, (Table 1). The mean deviation for dead cells was higher in Expt 1 than in Expt 2 (ANOVA, $\mathrm{p}=0.04$, and MRT test).

\section{Date effects on immune parameters}

Date effect was only significant for 2 immune parameters, the PDC and lysozyme activity (Table 1).

\section{Challenge effects on immune parameters}

Challenge with Vibrio tapetis caused significant changes in all studied parameters, except protein contents (Table 1). 


\section{Interaction factors on immune parameters}

Multifactor ANOVA analysis

There were 2 main significant interactions showing the effect of temperature combined with other factors on the measured immune parameters. The interaction of temperature and inoculation had a significant effect on the mean deviation of THC ( $p=0.0246$, ANOVA). The interaction of temperature and date also showed a significant effect on the mean deviation of lysozyme $(p=0.0001$, ANOVA $)$.

\section{Factorial correspondence analysis}

A factorial correspondence analysis was performed on the mean values of all immune parameters measured in Expt 1 (Fig. 7). The first 2 axes were the principal contributors to the total inertia $(76.7 \%$ for Axis $1 ; 14.7 \%$ for Axis 2$)$. The other axes were under $10 \%$. Relative and absolute contributions to these 2 first axes allowed the identification of 2 gradients, a temperature and an inoculation gradient. For the temperature gradient, mean data corresponding to low temperature $\left(8^{\circ} \mathrm{C}\right)$ and lysozyme were isolated together in the positive values of the Axis I. Axis 2 isolated all the data obtained at the higher temperature $\left(21^{\circ} \mathrm{C}\right)$ and the LAP immune parameter in the negative values. Factorial correspondence analysis confirmed that temperature had a modulating effect, particularly on lysozyme and LAP activities. The contribution of LAP and lysozyme were high and represented on average 41 and $27 \%$ of the total, respectively, for Axis 1. Mean data corresponding to control data and THC and lysozyme were isolated together in the positive values of Axis 1 for the inoculation gradient. The positive values in Axis 2 isolated almost all the Vibrio tapetis-inoculated clam data and PDC. This factorial correspondence analysis study showed that $V$. tapetis inoculation had a strong effect on the PDC parameter. The contribution of PDC was very high for Axes 1 and 2, representing 23 and $51 \%$ of the total, respectively.

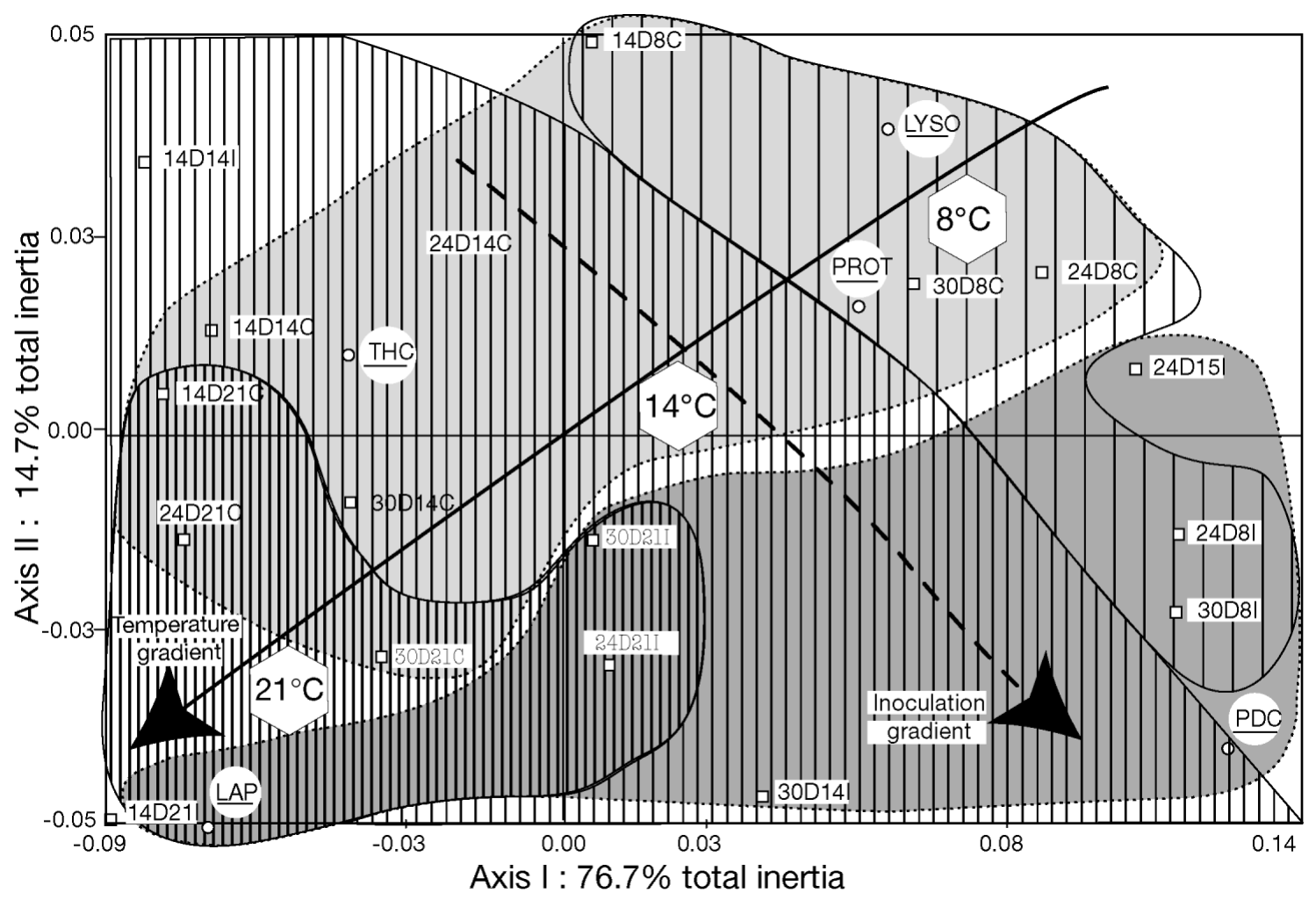

Fig. 7. Vibrio tapetis infecting Ruditapes philippinarum. Factorial correspondence analysis on mean data of immune parameters of Expt 1. The temperature gradient from 8 to $21^{\circ} \mathrm{C}$ is noted (areas surrounded by continuous line and vertically hatched; arrow with solid line). Inoculation gradient from control to $V$. tapetis challenged clams (areas surrounded by dotted line and greyshaded; arrow with dashed line). THC: total hemocyte counts; PDC: percentage of dead cells; LAP: leucine amino-peptidase; LYSO: lysozyme; PROT: protein. The mean of each data set was expressed with an abbreviation: XD (14D, 24D or 30D) corresponds to the day of sampling, the number $(8,14$ or 21$)$ to the temperature $\left({ }^{\circ} \mathrm{C}\right)$ of clam incubation and the letter $(\mathrm{C}$ or $\mathrm{I})$ to the clam status (Control or Inoculated) 


\section{DISCUSSION}

In marine invertebrate diseases, prevalence is often controlled by environmental factors. Temperature is a major factor that can explain spatial and temporal variations of disease prevalence (Harvell et al. 1999). In the present study, experimental Vibrio tapetis contaminations carried out at different temperatures demonstrated relatively low prevalence (6 to $20 \%$ ) at $21^{\circ} \mathrm{C}$ in comparison to $100 \%$ prevalence at both 14 and $8^{\circ} \mathrm{C}$ after 4 wk challenge. The high temperature $\left(21^{\circ} \mathrm{C}\right)$ not only retarded development of the disease, but enhanced recovery processes. Temperature has been repeatedly reported to be a key factor in bacterial diseases of poikilotherms (Lauckner 1983, Sindermann 1990). Temperature influences the severity of disease in several bivalve species, particularly during larval stages (see review of Sindermann 1990). Summer mortalities attributed to Vibrio sp. infections and high water temperature are frequently described, particularly in Crassostrea gigas (Lipovsky \& Chew 1972, Lacoste et al. 2001, Waechter et al. 2002). Generally, major shellfish diseases become more severe with higher temperatures, and experimental challenge with pathogens has shown that high temperatures enhance disease prevalence (Elston et al. 1982, Chu \& La Peyre 1993). However, a few cold water diseases have also been reported in bivalves. For instance, Mikrocytos mackini, the agent of the Denman Island disease in the oyster C. gigas, did not develop in oysters held at temperatures above $14^{\circ} \mathrm{C}$. Temperatures below $10^{\circ} \mathrm{C}$ are required for the development of the disease and associated mortalities (Hervio et al. 1996, Bower et al. 1997). In the case of $\mathrm{BRD}$, the present results are in accordance with the field survey along the French Atlantic coast and with epidemiological studies performed in Europe; this bacterial disease is reported mainly in areas where seawater temperature is relatively low in summer (in northern Europe, i.e. England, Ireland, Brittany, and in southen Europe, i.e. Galicia, Portugal) (Paillard et al. 1994, 1997). In Italy, sporadic cases of BRD have been reported in lagoons in Venice during winter, but these infections have not spread along the Adriatic coast. The very low level of BRD in Italy may be primarily due to the fact that higher temperatures (up to $21^{\circ} \mathrm{C}$ ) in the sediment during the warm seasons limit $V$. tapetis proliferation.

Temperature is also a key factor modulating the host immune defense in invertebrates (Thompson et al. 1978, Fisher 1988). Laboratory experiments reported here clearly demonstrate that temperature significantly modulates the host immune status and also the response of clams after challenge with Vibrio tapetis. The impact of temperature on hemolyph characteris- tics was analysed in 2 ways: (1) whether it produced an effect on the level of defense parameters in control and challenged clams, and (2) whether it modifies the kinetics of the immune response of challenged clams during disease development. Temperature effect combined with BRD development and immune parameters will be discussed subsequently.

In the present study, temperature predominantly affected the total hemocyte counts, the percentage of viable cells, and the activity of LAP, whether the clams were challenged or not. For control and challenged clams from both experiments, these parameters were generally higher at $21^{\circ} \mathrm{C}$ than at 8 and $14^{\circ} \mathrm{C}$. This result can be explained by the assumed higher metabolism of Ruditapes philippinarum which originated in the Philippines where water temperatures are higher (Goulletquer 1989, Laruelle 1999). Heartbeat rate in Crassostrea virginica and $\mathrm{O}_{2}$ consumption, respiration rate and filtration rate in $R$. philippinarum are highest at elevated temperatures (Feng 1965, Mann 1979). Therefore, an elevated metabolism at higher temperatures in clams could explain the higher concentration of circulating hemocytes due either to a higher production rate of hemocytes at $21^{\circ} \mathrm{C}$ or mobilisation of hemocytes from tissues towards the hemolymph. The THC in many marine bivalves, such as Mytilus galloprovincialis and C. gigas, follow a seasonal pattern, and are positively correlated with water temperature (Oubella 1996, Carballal et al. 1998). Similar increases in circulating hemocytes at high temperatures have also been observed during experimental studies in C. virginica (Chu \& La Peyre 1993) and in the gastropod Biomphalaria glabrata (Stumpf \& Gilbertson 1978). As in controls, challenged clams incubated at $21^{\circ} \mathrm{C}$ displayed higher THC than specimens incubated at 8 and $14^{\circ} \mathrm{C}$. Similar results have also been demonstrated in C. virginica challenged with the protozoan Perkinsus marinus (Chu \& La Peyre 1993). The PDCs in hemolymph can be used as an indicator of the physiological state of bivalves. In laboratory and field experiments, high percentages of dead hemocytes (up to $20 \%$ ) have been measured in hemolymph and extrapallial fluids of oysters and clams and were often followed by mortalities (Paillard et al. 1996, Paillard, unpubl. data) Thus, the high percentages of dead hemocytes measured here at $8^{\circ} \mathrm{C}$ either in control or inoculated clams, could reflect poor physiological condition for this exotic species at lower temperatures. Autophagocytosis is one of the principle ways to eliminate dead hemocytes from circulation (Scro \& Ford 1990). In R. philippinarum, phagocytosis activity is significantly lower at 8 and $14^{\circ} \mathrm{C}$ than at $21^{\circ} \mathrm{C}$ (Allam 1998). Thus, the high percentages of dead hemocytes at $8^{\circ} \mathrm{C}$ could be the result of low autophagocytic activity at lower temperatures. In the case of BRD, the 
humoral response has been focused on lysosomal enzymes such as LAP, an exopeptidase which is particularly important because of its ability to hydrolyse protein components of foreign bacterial membranes (Hiroi et al. 1992). The present study has shown that LAP activity was positively correlated with temperature in challenged and control clams. In both cases, this positive correlation suggests that enzyme levels are enhanced in hemolymph with increased temperature. Hypersynthesis of hemolymph enzymes is a phenomenon which plays a protective role by acting against invading micro-organisms including bacteria (Mohandas \& Cheng 1985). However, the activity of LAP remained lower following exposure to low temperature $\left(8^{\circ} \mathrm{C}\right)$. The observed lower level of LAP in cold temperature exposed-clams may reveal a weakened physiological state. These results suggest that lower temperature is a stressor that may cause immunosuppression. Decrease of this humoral defense mechanism with low temperature may interfere with the immunocompetent functions of the immune system, and may increase the susceptibility of populations to Vibrio tapetis in the field. Numerous publications have described the effect of salinity on LAP activity, but to date, no one has reported a temperature effect.

Temperature also affects the pattern of the immune response of clams following challenge with Vibrio tapetis (Table 2). Clams maintained at $14^{\circ} \mathrm{C}$, which corresponds to standard conditions used during experimental infection since 1990, exhibited immune response patterns in accordance with kinetics described in previous publications (Oubella et al. 1993, 1994, Paillard et al. 1994, Allam et al. 2000b). The kinetics of the immune response in clams incubated at $8^{\circ} \mathrm{C}$ was relatively close to the one in clams held at $14^{\circ} \mathrm{C}$, showing an early increase in THC, LAP and lysozyme activities that reach maximal values about $2 \mathrm{wk}$ after challenge. These 3 parameters decreased thereafter and relatively low values were maintained up to $4 \mathrm{wk}$ following contamination. Decreases in these hemolymph parameters in the late phase could be a consequence of the continuous migration of hemocytes from hemolymph to the site of infection (i.e. extrapallial fluids) (Paillard et al. 1994). In the present study, in both experiments on Day 30, the BCI was generally higher at $14^{\circ} \mathrm{C}$ than at 8 and $21^{\circ} \mathrm{C}$ for most of the immune parameters (THC, PDC and LAP). This confirms that $14^{\circ} \mathrm{C}$ is the best temperature to detect changes of these parameters following challenge with $V$. tapetis. On the other hand, the incubation of clams at $21^{\circ} \mathrm{C}$ had a greater effect than $14^{\circ} \mathrm{C}$ on the pattern of lysozyme activity during the development of BRD. In control clams, lysozyme activity was negatively correlated with temperature. This result is in accordance with data reported in Crassostrea virginica by Chu \& La
Peyre (1993). In contrast, challenged clams displayed an increase of lysozyme activity at $21^{\circ} \mathrm{C}$, reaching values comparable to those measured in control clams maintained at $8^{\circ} \mathrm{C}$. This increase in lysozyme activity could be associated with the recovery process occurring at $21^{\circ} \mathrm{C} 3 \mathrm{wk}$ post-challenge. Lysozyme may be one of the immune parameters playing a major role against the proliferation or invasion of microorganisms such as gram-positive and -negative bacteria (Cheng et al. 1975, 1977, Cheng 1983, Lopez et al. 1997). In addition to direct bactericidal activity, lysozyme could enhance the activity of other anti-bacterial molecules which could be directly active against $V$. tapetis, a process already described for other gramnegative bacteria by Smith et al. (1995).

In the present study, protein levels in clam hemolymph were not dependent upon the temperature at which the clams were incubated. This result is unlike the findings of Chu \& La Peyre (1993), who described a decrease in protein levels in the hemolymph of Crassostrea virginica maintained at high temperatures, associated with a decrease in condition index. In Manila clams, recent experiments performed in similar laboratory conditions but during another period of the year (January and February) compared to the present study have shown a decrease of protein and condition index in individuals maintained at $21^{\circ} \mathrm{C}$ compared to those at 13 and $8^{\circ} \mathrm{C}$ (Paillard unpubl. data). This lower protein level and condition index at high temperature could be due to high metabolism and nutritional stress compared to clams maintained at 8 and $14^{\circ} \mathrm{C}(\mathrm{Chu} \&$ La Peyre 1993).

The present study also demonstrated good reproducibility between experiments and underlines the strong effect of temperature on host immune response in clams. To explain minor differences in immune parameters between both experiments, infection severity must be considered, i.e. a delay in BRD group development in Expt 2 compared to the Expt 1.

Temperature has a strong effect on BRD development, which means that the elevated temperature not only inhibits the development of the BRD syndrome but also enhances the recovery processes. In the present study, BRD development was related to a significant decrease in hemocyte viability and LAP activity in hemolymph. In contrast, the recovery process was associated with high levels of these 2 immune parameters and also with an increase in lysozyme activity. During the different phases of the disease, the decrease in protein concentration in the hemolymph can be seen and associated with the 2 processes occuring during $\mathrm{BRD}$, the conchiolin deposit and the shell repair. These 2 external defense mechanisms may require higher protein concentrations compared to normal shell growth. 
In conclusion, temperature can be considered a key factor controlling BRD development and defense parameters. The factorial correspondence analysis confirms the modulating effect of temperature on hemolymph defense parameters, particularly on lysozyme and LAP parameters. In our opinion, in the case of the BRD, the favourable immune status at $21^{\circ} \mathrm{C}$ may confer on the clam a better capacity to fight the disease agent and therefore enable it to recover more easily. This hypothesis is in accordance with other experiments in our laboratory which have shown that the pathogen was still present at lower concentrations (near the detection limit of ELISA, $10^{4} \mathrm{CFU} \mathrm{m}^{-1}$ ) in the host maintained at $21^{\circ} \mathrm{C}$, but it is not capable of inducing BRD symptoms or mortalities (Paillard unpubl. data). Transfer of clams from 21 to $14^{\circ} \mathrm{C}$ has shown that these individuals were able to develop BRD (Paillard unpubl. data). In the present study, high hydrolytic enzyme activities in the hemolymph, associated with high numbers of viable and phagocytic hemocytes at high temperatures, probably help fight the disease agent and maintain low levels of pathogenic bacteria. Low BRD prevalence (14\%) by pallial challenge, takes at least $10^{3} \mathrm{UFC} \mathrm{ml^{-1 }}$ of $\mathrm{Vib}$ rio tapetis, so if the clam can maintain the $V$. tapetis level in the extrapallial fluids under this critical concentration, it could be considered asymptomatic. To better understand the effect of temperature on hostpathogen interactions, further experiments are in progress to investigate how temperature and other environmental factors such as salinity or trophic resources modulate the immune competency of hemocytes against bacterial pathogens, as well as the virulence factors of $V$. tapetis.

Acknowledgements. This study has been carried out with financial support from the National Program of Coastal Ecosystem ('Programme National Ecosysteme Côtier, PNEC'). We are greatly indebted to K. A. Ashton-Alcox for correcting this manuscript. Contribution No. 912 of the IUEM (Brest, France)

\section{LITERATURE CITED}

Afoke AO, Eeg-Olofsson O, Hed J, Kjellman NM, Lindblom B, Ludvigsson J (1993) Seasonal variation and sex differences of circulating macrophages, immunoglobulins, and lymphocytes in healthy school children. Scand J Immunol 37:209-215

Allam B (1998) Rôle des fluides extrapalléaux des bivalves dans la défense immunitaire. Cas de la maladie de l'anneau brun chez la palourde d'élevage, Ruditapes philippinarum. Thèse de doctorat de l'Université de Bretagne Occidentale, Brest

Allam B, Paillard C (1998) Defense factors in extrapallial fluids of clams. Dis Aquat Org 33:123-128

Allam B, Paillard C, Maes P (1996) Localization of the pathogenic Vibrio P1 in clams affected by the brown ring disease. Dis Aquat Org 27(2):81-88
Allam B, Paillard C, Auffret M (2000a) Alterations in hemolymph and extrapallial fluid parameters in the Manila clam, Ruditapes philippinarum challenged with its pathogen, Vibrio tapetis. J Invertebr Pathol 76:63-69

Allam B, Paillard C, Howard A, Le Pennec M (2000b) Isolation of the pathogen Vibrio tapetis and defense parameters in Manila clam, Ruditapes philippinarum, cultured in England. Dis Aquat Org 41(2):105-113

Allam B, Paillard C, Ford SE (2002) Pathogenicity of Vibrio tapetis, the etiologic agent of brown ring disease in clams. Dis Aquat Org 48:221-231

Auffret M, Oubella R (1994) Cytometric parameters of bivalve molluscs : effect of environmental factors. In: Stolen JS, Fletcher TC (eds) Modulators of fish immune responses. SOS Publication, Fair Haven, NJ, p 23-32

Auffret M, Oubella R (1995) Cytological and cytometric analysis of bivalve mollusc hemocytes. In: Stolen JS, Fletcher TC, Smith SA, Zelikoff JT, Anderson RS, Soderhall K, Kaattari SL, Weeks-Perkins BA (eds) Techniques in fish immunology, Vol 4. SOS Publications, Fair Haven, NJ, p 55-63

Borrego JJ, Castro D, Luque A, Paillard C, Maes P, Garcia MT, Ventosa A (1996) Vibrio tapetis sp. nov., the causative agent of the Brown ring disaese affecting cultured clams. Int J Syst B 46:480-484

Bower SM, Hervio D, Meyer GR (1997) Infectivity of Mikrocytos mackini, the causative agent of Denman Island disease in Pacific oysters Crassostrea gigas, to various species of oysters. Dis Aquat Org 29:111-116

Bradford MM (1976) A rapid and sensitive method for the quantitation of microgram quantities of protein utilizing the principal of protein-dye binding. Anal Biochem 72: $248-254$

Carballal MJ, Villalba A, Lopez C (1998) Seasonal variation and effects of age, food availability, size, gonadal development, and parasitism of the hemogram of Mytilus galloprovincialis. J Invertebr Pathol 72:304-312

Cheng TC (1981) Bivalves. In: Ratcliffe NA, Rowley AF (eds) Invertebrate blood cells, Vol 1. Academic Press, London, p 231-300

Cheng TC (1983) The role of lysozymes in molluscan inflammation. Amer Zool 23:129-144

Cheng TC (1992) Selective induction of release of hydrolase from Crassostrea virginica hemocytes by certain bacteria. J Invertebr Pathol 59:197-200

Cheng TC, Rodrick, GE, Foley DA, Koehler SA (1975) Release of lysozyme from hemolymph cells of Mercenaria mercenaria during phagocytosis. J Invertebr Pathol 25:261-265

Cheng TC, Chorney MJ, Yoshino TP (1977) Lysozyme-like activity in the hemolymph of Biomphalaria glabrata challenged with bacteria. J Invertebr Pathol 29:170-174

Chu FE (1988) Humoral defense factors in marine bivalves. Am Fish Soc Spec Publ 18:178-188

Chu FLE, La Peyre JF (1993) Perkinsus marinus susceptibility and defense-related activities in eastern oysters Crassostrea virginica: tempertaure effects. Dis Aquat Org 16: 223-234

Demas GE, Nelson RJ (1996) Photoperiod and temperature interact to affect immune parameters in adult male deer mice (Peromyscus maniculatus). J Biol Rhythms 11(2): 94-102

Demas GE, Nelson RJ (1998) Photoperiod, ambient temperature, and food availability interact to affect reproductive and immune function in adult male deer mice (Peromyscus maniculatus). J Biol Rhythms 13(3):253-62

Elston R, Elliot EL, Colwell RR (1982) Conchiolin infection and surface coating Vibrio: shell fragility, growth depression 
and mortalities in cultured oysters and clams, Crassostrea virginica, Ostrea edulis and Mercenaria mercenaria. J Fish Dis 5:265-284

Feng SY (1965) Heart rate leucocyte circulation in Crassostrea virginica (Gmelin). Biol Bull (Woods Hole) 128: $198-210$

Feng SY, Canzonier WJ (1970) Humoral responses in the american oyster (Crassostrea virginica) infected with Bucephalus sp. and Minchinia nelsoni. Dis Fish Shellfish 5:497-510

Feng SY, Feng JS (1974) The effect of temperature on cellular reactions of Crassostrea virginica to the injection of avian eruthrocytes. J Invertebr Pathol 23:22-37

Fisher WS (1988) Environmental influence on host response: environmental influence on bivalve hemocyte function. Am Fish Soc Spec Publ 18:225-237

Fisher WS, Auffret M, Balouet G (1987) Response of European flat oyster (Ostrea edulis) hemocytes to acute salinity and temperature changes. Aquaculture 67:179-190

Fisher WS, Chintala MM, Moline MA (1989) Annual variation of estuarine and oceanic oyster Crassostrea virginica Gmelin hemocyte capacity. J Exp Mar Biol Ecol 127: 105-120

Goulletquer P (1989) Etude des facteurs environnementaux intervenant sur la production de la palourde japonaise d'élevage Ruditapes philippinarum. Thèse de Doctorat, Univ Bret Occ, $341 \mathrm{p}$

Harvell CD, Kim K, Burkholder JM, Colwell R and 9 others (1999) Emerging marine diseases-climate links and anthropogenic factors. Science 285:1505-1510

Hervio D, Bower SM, Meyer GR (1996) Detection, isolation and experimental transmission of Mikrocytos mackini, a microcell parasite of Pacific oysters Crassostrea gigas (Thunberg). J Invertebr Path 67:72-79

Hiroi Y, Endo Y, Natori Y (1992). Purification and properties of an aminopeptidase from rat-liver cytosol. Arch Biochem Biophys 294:440-445

Lacoste A, Jalabert F, Malham S, Cueff A, Gelebart F, Cordevant C, Lange M, Poulet SA (2001) A Vibrio splendidus strain is associated with summer mortality of juvenile oysters Crassostrea gigas in the Bay of Morlaix (North Brittany, France). Dis Aquat Org 46(2):139-45

Laruelle F (1999) Phénologie et déterminisme de la reproduction chez Ruditapes decussatus et $R$. philippinarum (Adams et Reeve) en Bretagne. Thèse de doctorat, Océanographie Biologique, Université de Bretagne Occidentale, Brest

Lauckner G (1983) Diseases of Mollusca: Bivalvia. In: Kinne O. (ed) Diseases of marine animals, Vol 2, Introduction, Bivalvia to Scaphopoda. Biologische Anstalt Hegoland, Hamburg, p 477-961

Lipovsky VP, Chew KK (1972) Mortality of the pacific oysters (Crassostrea gigas): the influence of the temperature and enriched seawater on oyster survival. Proc Natl shellfish Assoc 62:72-82

Lochmiller RL, Vestey MR, McMurry ST (1994) Temporal variation in humoral cell mediated immune response in a Sigmodon hispidus population. Ecology 75:236-245

Lopez C, Carballal MJ, Azevedo C, Villalba A (1997) Enzyme characterisation of the circulating haemocytes of the carpet shell clam, Ruditapes decussatus (Mollusca: Bivalvia). Fish Shellfish Immunol 7:595-608

Mann R (1979) The effect of temperature on growth, physiology, and gametogenesis in the manila clam Tapes philippinarum (Adams \& Reeve, 1850). J Exp Biol Ecol 38: 121-133

Mohandas A, Cheng TC (1985) Release pattern of aminopep- tidase from Biomphalaria glabrata hemocytes subjected to high-level bacterial challenge. J Invertebr Pathol 45: 298-303

Nelson RJ, Demas GE (1996) Seasonal changes in immune function. Q Rev Biol 71(4):511-48

Oubella R (1996). Immune responses in bivalve molluscs. Effects of environmental factors on the internal defense. $\mathrm{PhD}$ thesis, University of Brest

Oubella R, Maes P, Paillard C, Auffret M (1993) Experimentally induced variation in hemocyte density for Ruditapes philippinarum and Ruditapes decussatus (Mollusca, Bivalvia). Dis Aquat Org 15:193-197

Oubella R, Paillard C, Maes P, Auffret M (1994) Changes in hemolymph parameters in the manila clam Ruditapes philippinarum (Mollusca, Bivalvia) following bacterial challenge. J Invertebr Path 64:33-38

Oubella R, Maes P, Allam B, Paillard C, Auffret M (1996). Selective induction of hemocytic response in Ruditapes philippinarum (Bivalvia) by different species of Vibrio (Bacteria). Aquat Living Resour 9(2):137-143

Paillard C (1992) Etiologie et caractérisation de la Maladie de l'Anneau Brun chez la palourde d'élevage, Ruditapes philippinarum. Thèse de Doctorat, Vol. 2, Université de Brest

Paillard C, Maes P (1990) Etiologie de la maladie de l'anneau brun chez Tapes philippinarum: pathogénicité d'un Vibrio sp. CR Acad Sci Sér III Life Sci 310:15-20

Paillard C, Maes P (1994) The brown ring disease symptom in the manila clam, Ruditapes philippinarum: establishment of a classification system. Dis Aquat Org 19:137-146

Paillard C, Maes P (1995a). The brown ring disease in manila clam, Ruditapes philippinarum. Part 1. Ultrastrucural alterations of the periostracal lamina. J Invertebr Pathol 65:91-100

Paillard C, Maes P (1995b) The brown ring disease in manila clam, Ruditapes philippinarum. Part 2. Microscopic study of the brown ring symptom. J Invertebr Pathol 65:101-110

Paillard C, Percelay L, Le Pennec M, Le Picard D (1989) Origine pathogène de l'anneau brun' chez Tapes philippinarum (Mollusque, bivalve). C R Acad Sci Sér III Life Sci 309:235-241

Paillard C, Maes P, Oubella R (1994) Brown ring disease in clams. Annu Rev Fish Dis 4:219-240

Paillard C, Alcox K, Ford SE (1996) Changes in hemolymph and extrapallial fluid parameters in the american oyster Crassostrea virginica affected by the juvenile oyster disease. Aquat Living Resour 9(2):145-158

Paillard C, Maes P, Mazurie J, Claude S, Marhic A, Le Pennec $M$ (1997) Epidemiological survey of the brown ring disease in clams of Atlantic coast: role of temperature in variations of prevalence. Proceedings of VIIIe Symposium of the International Society for Veterinary Epidemiology and Economics, Vol 31/32(2). AEEMA Publications, Paris, p 14.03.1-14.03.3

Plana S (1995) Perturbations de la glande digestive et du métabolisme chez la palourde aquacole, Ruditapes philippinarum, affectée par la maladie de l'anneau brun. Doctorat d'Université, Université de Bretagne Occidentale, Brest

Plana S, Sinquin G, Maes P, Paillard C, Le Pennec M (1996). Variations in the biochimical composition of the juveniles of manila clam, Ruditapes philippinarum, infected by a Vibrio sp. Dis Aquat Org 24(3):205-213

Roch P (1999) Defense mechanisms and disease prevention in farmed marine invertebrates. Aquaculture 172:125-145

Scro RA, Ford SE (1990) An electron microscope study of disease progression in the oyster Crassostrea virginica 
infected with the protozoan parasite Haplosporidium nelsoni (MSX). In: Perkins FO, Cheng TC (eds) Pathology in marine science. Academic Press, Orlando, FL, p 229-254

Sinderman CJ (1990) Principal disease of marine fish and shellfish, Vol 1. Academic Press, New York

Shugar D (1952) Measurement of lysozyme activity and the ultraviolet inactivation of lysozyme. Biochem Biophys Acta 8:302-309

Smith VJ, Swindlehurst RJ, Johnstos PA, Vethaak AD (1995). Disturbance of host defence capability in the common shrimp, Crangon crangon, by exposure to harbor dredge spoils. Aquat Toxicol 32:43-58

Editorial responsibility: Albert Sparks,

Seattle, Washington, USA
Stumpf JF, Gilbertson, DE (1978) Hemocytes of Biomphalaria glabrata: factors affecting variability. J Invert Pathol 32: $177-181$

Thompson RJ, Bayne CJ, Moore MN, Carefoot TH (1978) Haemolymph volume, changes in the biochemical composition of the blood, and cytological reponses of the digestive cells in Mytilus californianus Conrad, induced by nutritional, thermal and exposure stress. J Comp Physiol 127:287-298

Waechter M, Le Roux F, Nicolas JL, Marissal E, Berthe F (2002) Characterization of pathogenic bacteria of the cupped oyster Crassostrea gigas. C R Biol 325(3):231-238

Submitted: February 5, 2003; Accepted: November 7, 2003 Proofs received from author(s): June 7, 2004 